\title{
LITERARY AND ARTISTIC PROPERTY (INCLUDING COPYRIGHT) AS SECURITY: PROBLEMS FACING THE LENDER
}

\author{
LEON KAPLAN*
}

In order to keep this article within manageable limits both as to scope and length, the writer makes the following assumptions and "ground rules."

So far as possible, the problems discussed will be limited to those which arise by reason of the character of the security involved; a lender who relies upon literary and artistic property as security will be confronted with many of the same problems which face lenders in general or lenders secured by ordinary tangible property, but this paper will concentrate upon the unique or at least special difficulties which face lenders who depend upon the particular security herein discussed. It is assumed that the relationship of the parties is simply borrower and lender, and that the security consists solely of literary or artistic properties. The efficacy of devices to transform the transaction into one other than a loan is not of concern. This paper will not deal with loans secured by literary or artistic material which has become part of other collateral; to some extent, for example, a lender secured by a motion picture or an assignment of royalties of a published literary work must consider certain of the problems presented below; nevertheless, there is excluded from consideration situations in which tangible or other collateral constitutes the basic security.

Since this article deals primarily with security problems, it will not attempt to draw distinctions between literary property on the one hand and artistic property on the other. "Artistic properties" consist of such material as musical compositions, maps, works of art and reproductions of works of art, drawings, photographs, pictorial illustrations, designs, sketches, and dance routines. It is believed that from a security aspect the important difference is between copyrighted material on the one hand and uncopyrighted material on the other, and that the distinction between literary and artistic property is not of real significance.

When discussing copyrighted material, it will be assumed that the copyright proprietor has made the necessary applications to the Register of Copyrights of the United States, has affixed the necessary notices, and has otherwise fulfilled the requirements necessary to secure a valid United States copyright. Except where otherwise noted, discussions of the problems relating to the hypothecation of copyright will refer to the hypothecation of the entire copyright by the copyright proprietor.

Historically, literary and artistic properties had little economic significance and were of dubious value as collateral. Consequently cases involving hypothecations of this type of material are not numerous. There is still no established source of

*A.B. x930, LL.B. 1932, University of Southern California; member of the California bar. 
loans for this type of security, but with the development of the entertainment business and in particular the coming of age of the motion picture and television industries, transactions in which literary material is the basis of a loan are becoming more frequent. These transactions are now arising out of negotiations in which a company desiring to produce a motion picture, a television production or a play, requires funds in its early stages of production for preparatory work and has no collateral to offer at that stage except its literary rights.

Finally, this article limits itself to a consideration of those problems which confront a lender making a loan after receiving competent legal advice; problems which arise through faulty draftsmanship or which could have been avoided in the first instance by the selection of the proper instruments, compliance with required formalities or the inclusion in the instruments of various safe-guarding provisions, will not be dealt with here.

\section{Copyrighted Material}

\section{A. Unpublished Works}

Section 4 of the Copyright Act extends the privilege of copyright protection to "all the writings of an author." Any artistic or literary work which meets this definition may be copyrighted under Section ro of the Act by publication with notice of copyright affixed to each copy of the work published or offered for sale in the United States. ${ }^{2}$ Section 12 of the Act extends the privilege of copyright protection to works, copies of which are "not reproduced for sale," i.e., so-called unpublished works. ${ }^{3}$ But artistic and literary works which may be copyrighted as unpublished works include only the works enumerated in Section I2: lectures or similar productions; dramatic, musical or dramatico-musical compositions; motion picture photoplays; photographs; motion pictures other than photoplays; works of art; plastic works; and drawings."

The sections of the Copyright Act which deal with the mortgaging and assignment of copyrights ${ }^{5}$ make no distinction between copyrights upon published and those upon unpublished works. It would seem, therefore, that a copyright upon an unpublished work may be transferred or hypothecated under the Copyright Act in the same manner and to the same extent as a copyright upon a published work.

One problem must be kept in mind when drafting a mortgage of a copyright

${ }^{1} 17$ U. S. C. $\S_{4}$ (Supp. 1952).

${ }^{2}$ Id. $\S$ Io.

${ }^{3} 1 d$. $\$ 12$.

‘ Horace G. Balt, The Law of Copyright and Literary Property 98 (1944). Section 5 of the Copyright Act (17 U. S. C. \$5) (Supp. 1952) specifies 13 different classes of works for copyright registration purposes. Five classes are not eligible for copyright as unpublished works under Section 12 since they are not enumerated in that section: books; periodicals; maps; reproductions of works of art; and prints and pictorial illustrations. Section 5 provides that the classification of works made therein shall not be held to limit the subject matter of copyright as defined in Section 4 of the Act. Accordingly, it would follow that other kinds of artistic and literary works, not included within the classes enumerated in Section 5, but which meet the definition of "writings of an author" and which are not expressly enumerated in Section I2, also are not eligible for copyright as unpublished works.

${ }^{5}$ I7 U. S. C. $\$ \$ 28$ and 30 (Supp. 1952). 
upon an unpublished work. Such a copyright may lose its validity upon publication of the work. ${ }^{6}$ If the work is published in compliance with the rules governing the securing of a copyright upon publication, continued copyright protection is assured; if it is published without such compliance, the works falls into the public domain.?

What can the mortgagee do to prevent the copyright proprietor-mortgagor from publishing the work without notice of copyright and thereby destroying the copyright? As a minimum precaution, the mortgage itself should contain a clear and unequivocal covenant on the part of the mortgagor not to authorize or permit the publication of the work without the consent of the mortgagee, or, at least, without complying with the requirements of the Copyright Act for securing a copyright upon published work. The effectiveness of such a clause, is, however, doubtful.

Section Io provides that the first publication of a "work" with the "required" notice secures the copyright; but it implies that a failure to affix the notice upon each copy, later published "by authority of the copyright proprietor," will "forfeit" the copyright. And so the cases have held. ${ }^{8}$ In American Press Association v. Daily Story Publishing Company, ${ }^{\text {}}$ the licensee of a copyrighted story published the story without affixing to the printed copies thereof the statutory notice of copyright, in breach of an express provision contained in the agreement with the copyright proprietor. The United States Court of Appeals for the Seventh Circuit held that publication of the story did not work a forfeiture or destruction of the copyright, on the theory that performance by the licensee of its contractual obligation to affix the statutory notice to all copies of the story published by it was a condition upon its license, and that the licensee's wrongful conduct in violating this obligation should not be visited upon the licensor. In such a case, it may properly be said that the publication of the work is not "by authority of the copyright proprietor." But in Daly v. Walrath, ${ }^{10}$ it was held that an author can destroy his licensee's common law rights by publication, regardless of the fact that this may render the author liable to his licensee for damages for breach of contract.

It would appear that if the copyright mortgagor authorizes or gives his consent to the publication of the work, such publication is "by authority of the copyright proprietor," and if the publication is made without the statutory notice, forfeiture of the copyright will result, notwithstanding a provision in the mortgage prohibiting such publication. Nevertheless, since there is no case authority directly in point, and since the copyright mortgagee would at least be left with a cause of action against his mortgagor for breach of contract, the mortgage should contain a provision of the kind referred to above.

- Patterson v. Century Productions, 93 F. 2d 489 (2d Cir. 1937). 7Ibid. See also: Lumiere v. Pathe Exchange, 275 Fed. 428 (2d Cir. I92I); Riosedale v. News Syn-
dicate, 39 F. Supp. 357 (S. D. N. Y. I94I).

${ }^{8}$ E.g., Mifflin v. Dutton, x9o U. S. 265 (1903); Louis De Jonge v. Breuker \& Kessler Co., 235 U. S.

33 (rgr4); National Comics Publication v. Fawcett Publications, 19r F. 2d 594 (2d Cir. 1941).

I20 Fed. 766 (7th Cir. 1902).

${ }^{10} 40$ App. Div. 220, 57 N. Y. Supp. 1125 (2d Dep't 1899). 


\section{B. General Comments}

The first and most important decision which faces the lender is the selection of the form of security instrument he will require of the borrower and the determination of what substantive provisions he can properly include therein. The only sections of the Copyright Act which deal with the hypothecation of copyrights are Sections 28 and $30^{11}$ Section 28 provides that:

Copyright secured under this title or previous copyright laws of the United States may be assigned, granted or mortgaged by an instrument in writing signed by the proprietor of the copyright, or may be bequeathed by will.

\section{Section 30 reads as follows:}

Every assignment of copyright shall be recorded in the Copyright Office within three calendar months after its execution in the United States or within six calendar months after its execution without the limits of the United States, in default of which it shall be void as against any subsequent purchaser or mortgagee for valuable consideration, without notice, whose assignment has been duly recorded.

Although Section 30 refers to "assignment of copyright" and does not expressly mention the word "mortgage," it seems clear that a copyright mortgage is subject to the provisions of this section. ${ }^{12}$

Generally, lender's counsel must choose between a mortgage, a pledge, or a grant or assignment which, though absolute on its face, is given to secure performance of the debtor's obligations. Counsel can expect to find little assistance from cases decided under the Copyright Act. Only two reported cases have been found in which any issue relating to a copyright mortgage was involved. ${ }^{13}$ Caution would seem to dictate the use of an instrument which clearly and unequivocally purports to be a mortgage rather than one which purports to be an agreement of pledge.14

1117 U. S. C. $\$ \$ 28$ and 30 (Supp. 1952).

${ }^{12}$ In In re Leslie-Judge Company, 272 Fed. 886 (2d Cir. 1921), the court held in effect that a mortgage of copyrights was void as against the trustee in bankruptcy of the mortgagor since the mortgage, apparently, had not been recorded in the Copyright Office. In Waterman v. MacKenzie, I38 U. S. 252 (1891) the United States Supreme Court interpreted an analogous section of the Patent Act as requiring the recordation of patent mortgages. This section provided: "An assignment, grant or conveyance shall be void as against any subsequent purchaser or mortgagee for a valuable consideration, without notice, unless it is recorded in the Patent Office within three monthis from the date thereof." Construing this section, the Court pointed out that (p. 256): "An assignment of the entire patent ... may be either absolute or by way of mortgage. ..." The language of Section 30 , itself, supports an interpretation that the term "assignment" includes mortgages, as well as outright assignments. The section states that an unrecorded assigament shall be void as against any subsequent purchaser or mortgagee for valuable consideration, without notice, "whose assignment has been duly recorded," instead of "whose assignment or mortgage has been duly recorded."

${ }_{1 s}$ In re Leslie-Judge Company, 272 Fed. 886 (2d Cir. I92I); Republic Pictures Corporation v. Sccurity-First National Bank of Los Angeles, I97 F. 2d $76_{7}$ (9th Cir. 1952).

14 A pledge has been defined as a bailment of personal property to secure an obligation of the bailor. Jasies L. Brown, Personal. Property 560 (1936). The main distinction between a pledge and a chattel mortgage is that in the case of a pledge possession of the security is delivered to the creditor. Ibid. Although this distinction obviously tends to break down in the case of intangibles, the courts continue to label as "pledges" many security transactions involving intangibles where only symbolic or ostensible delivery of possession takes place. See Robbins, The Pledge as an Illinois Security Device, 3 I CrIr.-KENT L. REv. 99 (r953); Note, Security Interests Under Pledge Agreements, 5I YALE L. J. 43 I (1942). 
Use of the pledge device gives rise to a number of uncertainties and would seem to afford no advantages. Although no cases have been found involving an attempted pledge of copyright, at least two cases decided in the federal courts ${ }^{15}$ reflect judicial recognition that a patent is a proper subject for a pledge as well as for a mortgage. The opinions in these cases, however, do not consider whether authority for the pledge device is to be found in the Patent Act or in local state law. In view of the fact that the Copyright Act specifically authorizes the mortgaging of copyrights but is silent on the subject of pledges, there is some doubt whether authority for the pledge device can be read into the Act. On the other hand, it seems reasonably clear that Congressional silence on the subject is not to be taken as evidence of Congressional intent to proscribe this form of hypothecation of copyrights. If it be held that Congress has not legislated on the matter, expressly or sub silentio, it follows that reference must be made to state law to determine the validity and effect of a purported pledge of copyright. Such a reference would raise difficult questions of choice of law, ${ }^{16}$ and, in many instances, give rise to uncertainties as to the lender's rights under the pledge instrument. ${ }^{17}$ Moreover, while compliance with the recordation provision of the Copyright Act probably would not be required to protect the pledgee's rights against subsequent purchasers or encumbrancers if state law is deemed controlling on the subject, proper respect for the uncertainties inherent in the transaction would in any event compel the lender to record the pledge instrument in the Copyright Office. Thus the main advantage of the pledge technique-the elimination of the formalities required to validate a mortgage-would be lost. ${ }^{18}$

Nor does there appear to be any real advantage to the utilization of an absolute assignment given in fact as security for a debt-even though its use is comparatively widespread. Once it is established that the assignment is given as security-and this fact may be established by parol evidence ${ }^{19}$-the courts will treat the assignment as

${ }^{15}$ Westmoreland Specialty Co. v. Hogan, 167 Fed. 327 (3d Cir. 1909); Western Battery \& Supply Co. v. Hazelett Storage Battery Co., 6I F. 2d 220 (8th Cir. 1932), cert. denied, 288 U. S. 608 (1933).

${ }^{18}$ See infra under Section $\mathrm{C}$ of this paper.

${ }^{17}$ If state law governs, at least two questions must be resolved: ( $x$ ) whether the governing jurisdiction recognizes an intangible such as a copyright as the proper subject of a pledge; and (z) what formalities, if any, must be complied with, under that state's law, in order to meet the minimal requirements of "delivery of possession" of the copyright to the pledgee, or of notice to third parties of the existence of the pledge. See: Robbins, The Pledge as an Illinois Security Device, 3 I Cur.-Kent L. Rev. 99 (I953).

${ }^{18}$ The lender might suffer an additional disadvantage in utilizing a security instrument which on its face purports to be an agreement of pledge. In Waterman v. MacKenzie, 138 U. S. 252 (18go), the United States Supreme Court held that a mortgagee of a patent, whose mortgage is duly recorded in accordance with the Patent Act, is entitled to maintain an action for infringement of the patent; the mortgagor has no standing to maintain such an action. The copyright mortgagee would seem to be entitled to the benefit of this rule. See Horace G. Bald, The Law of Copyright and Literary Property 552 (1944). But in Westmoreland Specialty Co. v. Hogan, and Western Battery \& Stpply Co, $v$. Hazelett Storage Battery Co., supra note 15 , it was held that the pledgor of a patent is cntitled to sue for infringements. Accordingly, a pledge, as distinguished from a mortgage, of a copyright might preclude the lender from maintaining an action for infringement of the copyright without joining his mortgagor in the action.

19 E.g., Paladini v. Durchman, 216 Cal. 212, 13 P. 2d 731 (1932). See Samuel W. Eager, The Law of Chattel Mortgages and Conditional Sales and Trust Receipts, 35 (1941). 
a mortgage. ${ }^{20}$ Foreclosure proceedings would then be required to eliminate the mortgagor's right of redemption and the advantages of a completed irrevocable transfer would disappear. Since a grant or assignment will not contain provisions customarily found in well-drafted mortgages (such as provisions relating to the holding of public or private sales, waiver of notice of the holding of such sales, waiver of right of redemption, and the like) many of the advantages which can be obtained by use of the mortgage form would be lost.

One point should be emphasized at this juncture. If the litigation or dispute involves the two original parties-the borrower and the lender-the form of the instrument probably does not make too great a difference. The courts, in the exercise of their equitable powers, will generally enforce the agreement and the security provisions thereof in accordance with the intent of the parties. ${ }^{21}$ Similarly, recordation is not a requirement as between the original parties. ${ }^{22}$ The real problem arises when the lender is confronted with claims of a bona fide purchaser or encumbrancer for value.

\section{Formal Requirements of Copyright Mortgages}

As we have seen, the Copyright Act merely provides that a copyright "may" be mortgaged by an instrument in writing signed by the copyright proprietor. ${ }^{23}$ Use of the permissive "may" suggests that an oral mortgage would be valid between the parties and those having notice. ${ }^{24}$ But since recordation is a prerequisite to the validity of a copyright mortgage as against subsequent bona fide purchasers and mortgagees for value ${ }^{25}$ and since a mortgage must be in writing to be recorded, the limited efficacy of a verbal mortgage is only of academic interest to the prudent lender.

There are comprehensive statutes in every state which provide for the filing or recording of personal property mortgages in local offices of record. ${ }^{26}$ And statutes

\footnotetext{
${ }^{20}$ E.g., Waterman v. MacKenzie, I38 U. S. 252 (I890).

${ }^{21}$ Glenn, The "Equitable Pledge," Creditors' Rights and the Chandler Act, 25 VA. I. Rev. 422 (1939).

${ }^{22}$ An unrecorded copyright assignment is valid between the parties. Banks Law Publishing Co. v. Lawyers' Cooperative Co., I69 Fed. 386 (2d Cir. I909). Likewise an unrecorded patent assignment is valid between the parties. See, e.g., John Tuman \& Sons, Inc. v. Basse, II3 F. 2d 928 (2d Cir. I940). ${ }^{23}{ }_{17}$ U. S. C. $\$ 28$ (Supp. I952).

24 For the view that an oral assignment of copyright would probably be valid between the parties, see Arthur W. Werr, American Copyright Law 545 (igr7).

${ }^{25}$ 17 U. S. C. $\$ 30$ (Supp. x952).

${ }^{20}$ I Leonard A. Jones, The Law of Chattel Mortgages and Conditional Sales 319 (6th ed., Bowers, x933). The object of these statutes is to provide a mode of giving notice to third parties of the existence of the chattel mortgage and its lien in lieu of the delivery of possssion of the mortgaged property to the mortgagee, which was the only means of accomplishing the same purpose at common law. Ibid. The statutes generally provide that a mortgage of personal property shall be recorded in the town or county of the mortgagor's residence. I $i d$. at 320 . In many state statutes it is provided that if the mortgagor is a non-resident of the state the mortgage shall be recorded in the county or town in which the property may be at the time the mortgage is executed. Ibid. Several state statutes provide that a mortgage of personal property shall be recorded not only in the county in which the mortgagor resides, but also in the county in which the property is located. Ibid. In other state statutes the mortgage need only be recorded in the county in which the property is situated at the time the mortgage is made. Ibid. As a prerequisite to recordation, local statutes generally require the mortgage to be acknowledged or witnessed in a specified manner. I id. at $420 \mathrm{et} \mathrm{seq.}$
} 
in many states prescribe in varying degrees of detail the form and mode of execution and other prerequisites to validity of such mortgages. ${ }^{27}$ To insure the validity of his mortgage against the whole world, must the copyright mortgagee comply with such local requirements, as well as the minimal requirements of the Copyright Act? Although two commentators have answered this question in the affirmative, ${ }^{28}$ one court has indicated that the mortgaging of copyrights is the exclusive concern of federal law. In In re Leslie-Judge Company, ${ }^{20}$ the United States Court of Appeals for the Second Circuit held that a mortgage purporting to cover intangibles, including copyrights, was invalid as against the trustee in bankruptcy of the mortgagor, since there was no local statute regulating intangibles, and "copyrights may be at once excluded from consideration because they can be mortgaged only under the federal copyright law." In view of the dearth of reported cases involving copyright mortgages, the law on this subject would appear to be far from settled..$^{30}$

It seems probable, however, that if a copyright mortgage is recorded in accordance with Section 30 of the Copyright Act, the validity of the mortgage will not be effected by failure to comply with local recording or filing statutes. In providing a mode of giving notice to third parties of the existence of copyright mortgages and assignments, it would appear that Congress has preempted the field and superseded state laws on the same subject. ${ }^{31}$ The fair implication of the language of Section 30-that an assignment or mortgage of copyright shall be void as against subsequent bona fide transferees for value unless recorded in accordance with the statute-is that an assignment or mortgage recorded in compliance therewith shall be valid as against such third parties. The conclusion that Congress has preempted the field with respect to the subject of recordation would appear to be supported by cases decided under the Federal Ship Mortgage Act. ${ }^{32}$ Since its enactment in 1850 , this Act has contained provisions relating to the recordation of mortgages on "vessels of the United States" ${ }^{33}$ similar to the recording provisions of the Copyright Act." In a long

${ }^{2 \tau}{ }_{\text {I }} i d$. at 66 et seq. A California statute provides that the mortgage must be clearly cntitled on its face, apart from and preceding all other terms, as a mortgage of crops and chattels, or either, as the case may be. Cal. Crv. Code \$2956. In addition this statute prescribes the form in which the mortgage may substantially be made. Ibid. The statutory form contains the date of execution of the mortgage, the names of the mortgagor and mortgagee, description of the property mortgaged and the note or debt secured thereby, and the mortgagor's signature. Ibid. The California Supreme Court has held that the provisions of this statute must be strictly construed and that a mortgage which is not made in accordance therewith is invalid as against third parties. Kahriman v. Jones, 203 Cal. 254, 263 Pac. 537 (1928).

${ }^{28}$ Arthur W. Weil, American Copyright Law 56I (1917); Freeman, The Copyright as Security, I2 J. B. A. KAN. 257, 258 (1942).

${ }_{20} 272$ Fed. 886 (2d Cir. I92I).

${ }^{30}$ The statutes of the governing jurisdiction, i.e., the state to whose laws reference would be made under the applicable rule of the conflict of laws, may not, as a matter of statutory construction, apply to a mortgage of intangibles such as copyrights. The New York courts have held, for example, that the New York statute which requires a mortgage of "goods and chattels" to be filed in local offices of record, does not apply to a mortgage or assignment for security of an intangible and that therefore such an instrument need not be filed or refiled as prescribed by the statute. See, e.g., Niles v. Mathusa, 162 N. Y. 596,57 N. E. 184 (1900).

${ }^{31}$ See Allen v. Riley, 203 U. S. 347 (1906), discussed infra note 37.

${ }^{32} 4 \mathrm{I}$ STAT. 1000 (1920), 46 U. S. C. \$§gII et seq. (1946).

${ }^{33}$ The applicable provisions of the Ship Mortgage Act presently provide as follows: "No sale, con- 
line of cases, both federal and state courts uniformly have held that the recordation provisions of the Ship Mortgage Act supersede and exclude all state laws providing for the filing or recording of ship mortgages in local offices of record. ${ }^{34}$

Likewise, it would seem that if the copyright mortgage is in writing, and if it is signed by the copyright proprietor, its validity will be sustained notwithstanding non-compliance with local statutes prescribing the form and mode of execution of chattel mortgages. Since Congress has legislated on the subject and has declared that a copyright may be mortgaged in compliance with a few simple requirements as to form and execution, it appears reasonable to conclude that state statutes cannot impose additional requirements. Cases decided under the Patent $\mathrm{Act}^{35}$ and the Ship Mortgage Act $^{36}$ support this view. ${ }^{37}$

veyance, or mortgage which, at the time such sale, conveyance, or mortgage is made, includes a vessel of the United States, or any portion thereof, as the whole or any part of the property sold, conveyed, or mortgaged shall be valid, in respect to such vessel, against any person other than the grantor or mortgagor, his heir or devisee, and a person having actual notice thereof, until such bill of sale, conveyance, or mortgage is recorded in the office of the collector of customs of the port of documentation of such vessel, as provided in subdivision (b) of this section." 4I STAT. 1000 (I920), 46 U. S. C. \$92I(a) (I946).

${ }^{36}$ E.g.: White's Bank v. Smith, 7 Wall. 646 (U. S. I868); Aldrich v. Aetna Ins. Company, 8 Wall. 491 (U. S. 1869); Cunningham v. Tucker, I4 Fla. 25I (1873); Fleming v. Fire Ass'n, I47 Mich. 404 (1907); Foster v. Chamberlain \& Co., $4 \mathrm{I} \mathrm{Ala.} 158$ (1867); Wood v. Stockwell, $55 \mathrm{Me}$. 76 (1867); Mitchell v. Steelman, 8 Cal. 363 ( 1857 ); of. Imperial Diesel Engine Co. v. Criscuolo, 32 Cal. App. 2d 244,89 P. 2d 674 (1939), cert. denied, 308 U. S. 620 (1939), rehearing denied, 308 U. S. 639 (I939).

${ }^{35}$ In Welsbach Light Co. v. Cohn, I8I Fed. 122 (C. C. S. D. N. Y. I910), plaintiff's standing to maintain an action for patent infringement was contested by the defendant. Plaintiff's title to the patent in question was based on a purported assignment from the former owner, a corporation. This assignment was in writing signed by the assignor's president on behalf of assignor, and the president's signature had been acknowledged before a notary public. Defendant contended that the assignment was invalid since the acknowledgment was not in the form prescribed for corporate acknowledgments by the laws of New York, the state in which the assignment presumably was executed. The relevant section of the Patent Act then in effect provided that "every patent, or any interest therein, shall be assignable in law by an instrument in writing . . . and shall be acknowledged before any notary public. ..." The court rejected defendant's contention, stating (p. 127): "This [the Patent Act] is the statute upon which the question of assignment must rest. Patents are creatures of the federal statute, and it is within the province of Congress to provide the manner of their transfer."

${ }^{30}$ In Shaw v. McCandless, 36 Miss. 296 ( 1858 ) the Mississippi Supreme Court sustained the validity of a ship mortgage, which had been executed in the state of Louisiana, against the contention that under Louisiana decisions mortgages on vessels were not valid unless made according to "the usage and laws of commerce." The court held that even if the ship mortgage, which had been recorded in compliance with federal requirements, had not been made in accordance with "the laws and usages of commerce" as defined by the Louisiana courts, the mortgage nevertheless was valid since (p. 300) "when the law of Louisiana authorizes mortages according to the laws and usages of commerce, and Congress establishes the rule regulating the subject, that rule becomes the law of commerce in relation to the subject; and if it authorizes the execution and registration of mortgages upon vessels, all mortgages made and recorded according to the requirements of the Act must be valid." In The Gordon Campbell, 13I Fed. 963 (W. D. N. Y. 1904) the court held valid a ship mortgage which had been properly recorded in compliance with the Ship Mortgage Act, notwithstanding non-compliance with a local statute which provided that a mortgage given to secure a note, which does not on its face show that it is secured by a chattel mortgage, shall be absolutely void.

37 The enactment by Congress of Sections 28 and 30 of the Copyright Act probably has not deprived the states of the power to enact legislation on the subject of transfer or hypothecation of copyrights, provided that the matters regulated by such legislation do not fall within the ambit of Sections 28 and 30 . In Allen v. Riley, 203 U. S. 347 (Ig06), the United States Supreme Court upheld a Kansas statute which made it unlawful for any person to sell a patent right in any county in the state without first filing with the county clerk authenicated copies of the letters patent together with an affidavit affirming the genuineness of the letters and the authority of the affiant to sell the patented right. Defendant 
Since, with the possible exception of In re Leslie-Judge Company, there appears to be no case law directly in point, the cautious mortgagee would do well to insist that his copyright mortgage be drafted, executed, and recorded in accordance with local laws regulating the mortgaging of personal property, as well as with the requirements of the Copyright Act. But to what jurisdiction should reference be made? Here, lender's counsel is confronted with perplexing problems in the conflict of laws. Cases decided in the various jurisdictions, and even within the same jurisdiction, reflect a wide diversity of judicial opinion as to the proper rule of the conflict of laws to be applied in choosing the state law which determines the legal effect and validity of mortgages of personal property. ${ }^{38}$ According to the Restatement ${ }^{39}$ the validity and effect of a chattel mortgage are determined by the law of the state where the chattel is located at the time the mortgage is executed. Many states, however, follow the rule that these matters are to be governed by the law of the state in which the mortgage is executed. ${ }^{40}$ Since the rule of conflict of laws of the forum is applied in determining the choice of law to govern a given situation, ${ }^{41}$ lender's counsel must first pick out the state in which it seems most likely an action would be brought under the mortgage. In many instances the mortgagee will be a corporate lender doing business throughout the country, and mortgagor will be a producer who regularly commutes between New York, Hollywood, Chicago, and London. Under such circumstances, counsel's choice of the "likely forum" would hardly be reliable. Even after counsel makes his best guess as to the jurisdiction in which suit probably would be brought, he may be confronted with a further question. The jurisdiction selected as the "likely forum" may follow the Restatement rule that the validity and effect of personal property mortgages are determined by the law of the state where the property is located at the time the mortgage is executed. But it is clear that a copyright is an intangible without a situs in any particular jurisdiction; ${ }^{42}$ hence the Restatement rule would not be applicable to a copyright mortgage. What rule would the "likely forum" then apply to determine the state law which governs such a mortgage? It is submitted that these choice of law problems can probably be eliminated, or at least lessened, by inserting in the mortgage a provision providing that the validity and effect of a copyright mortgage is to be governed by the Copyright Act and the laws of a stated juris-

contended that the Kansas statute was invalid on the grounds that it infringed upon the exclusive power of Congress over patents and conflicted with the provision of the Patent Act regulating assignments of patents. The Court rejected these arguments, pointing out that in the interest of protecting its citizens from fraud Kansas has the right to legislate on this subject until Congress does so. Said the Court (p. 357): "The mere provision in the Federal statute for an assignment and its record as against subsequent purchasers, etc. is not such legislation as takes away the rights of the Statcs to legislate on the subject themselves in a manner neither inconsistent with nor opposed to the Federal statute."

${ }^{38}$ Stumberg, Chattel Security Transactions and the Conflict of Laws, 27 Iowa L. Rev. 528 (I942).

${ }^{30}$ Restatement, Conflict of Laws $\$ 265$ (1934).

${ }^{10}$ E.g., Kusser v. Sioux City Horse \& Mule Co., rg9 Iowa 200, 200 N. W. 404 (1922); Holt v. Mahoney, 60 S. D. I58, 244 N. W. 98 (1932).

I Restatearent, Conflict of Laws $\$ 7$ (I934).

${ }^{2}$ Stevens v. Gladding, I7 How. 448,45 I (U. S. 1854 ). 
diction. ${ }^{43}$ The copyright mortgage should then be prepared and recorded in accordance with the laws of that jurisdiction which are applicable to personal property mortgages in general.

It is appropriate, at this point, to call the reader's attention to a peculiarity in the provisions of Section 30. Under most recordation statutes a purchaser or encumbrancer is not concerned with claims which are recorded subsequent to his own. Section 30, however, provides that a mortgage of copyright is void as against subsequent purchasers or mortgagees, for valuable consideration, without notice, unless recorded within ninety days after its execution. Thus, if the copyright proprietor executed a mortgage to $A$ on February $\mathrm{I}$, and, without disclosing this fact, executed another mortgage to $B$ on February ro, $A$ 's mortgage would have priority over $B$ 's if recorded within ninety days from February I even though $B$ 's mortgage is recorded first. ${ }^{44} B$ would be obliged to withhold payment of sums due the mortgagor, or to cause the same to be held in escrow, for a period of ninety days from the date on which his mortgage was executed, in order to be certain that no previously executed assignment or mortgage recorded within the ninety-day period could obtain priority.

\section{Substantive Provisions of the Copyright Mortgage}

It is desirable for the protection of a mortgagee to include in the mortgage many substantive provisions, especially those relating to rights upon default. Provisions which give to the mortgagee upon default the power to sell the property at public or private sale, waiver or curtailment of notice of such sale, waiver of the right of redemption, confirmation of the right of the mortgagee to bid and purchase at the foreclosure sale, and the right to foreclose separately or en masse if more than one item of security is involved, are examples of the type of contractual protection mortgagees desire. A well-drafted mortgage should also secure future advances and advances made for the protection, improvement or maintenance of the security; a copyright mortgage should give the mortgagee a lien upon additional copyrights secured upon different versions of the same work. As pointed out above, it may also be important to insert restrictions upon publication by the mortgagor of the copyrighted work and upon the uses which the mortgagor may make of the work.

It is apparent that these matters are not regulated under the Copyright Act. In accordance with established principles, it seems that since Congress has not preempted the field by statutory regulations of its own, these matters will be governed by applicable local law. ${ }^{45}$ The draftsman may insert provisions of the kind described above so long as such provisions are valid under the laws of the governing state jurisdiction.

\footnotetext{
${ }^{63}$ See: Stumberg, Chattel Security Transactions and Conflict of Laws, 27 IowA. L. Rev. 528, 534 (1942).

44 See Herbert A. Howell, The Copyrighr LAw I73 (I952).

"See Cookson v. Louis Marx \& Co., 23 F. Supp. 6I5 (S. D. N. Y. I938) (holding that the question of capacity to make an assignment of patent is governed by the law of the state of assignor's domicile); Radio Corporation of America v. Cable Radio Tube Corporation, 66 F. 2d 778 (2d Cir. I933), cett. denied, 290 U. S. 703 (1934) (holding that a parol license to sell patented articles for 4 years was void under state statute of frauds).
} 


\section{E. Enforcement of the Copyright Mortgage}

One of the first questions which confronts a mortgagee who desires to foreclose his copyright mortgage through judicial proceedings is the question of jurisdiction. In I952 the only reported case on the subject-Republic Pictures Corporation v. Security First National Bank ${ }^{46}$ - was decided by the Court of Appeals for the Ninth Circuit. The facts of that case were as follows: In an earlier action the bank, a California corporation, obtained a decree of foreclosure by default in the United States District Court upon a copyright mortgage executed by mortgagor, a California corporation. Since there was no diversity of citizenship, the jurisdiction of the District Court depended on whether the proceeding was an ". . . action arising under any Act of Congress relating to patents, copyrights or trade marks." instituted the instant action for declaratory relief against Republic Pictures Corporation, the distributor of the motion picture upon which the copyright was secured. Republic contended that the decree of foreclosure in the earlier action was void since the Federal Court had no jurisdiction to hear the case. The District Court, in the declaratory relief action, rendered judgment for plaintiff Security Bank, holding that the federal courts have exclusive jurisdiction to foreclose copyright mortgages. ${ }^{48}$ This decision was reversed on appeal, the Court of Appeals holding that jurisdiction in such cases was vested exclusively in the state courts. The bank did not petition the Supreme Court to review this decision.

Consideration should be given to the possibility that the decision reached in the Republic case will not be followed in other jurisdictions or may ultimately be overruled by a decision of the United States Supreme Court in a similar case. A mortgagee obtaining a decree of foreclosure in a jurisdiction which ultimately follows a rule contrary to the rule of the Republic case may be confronted with a claim that his decree, and the title acquired thereunder, are void and that any exercise of dominion over the copyright constitutes a conversion. In order to minimize such risks it is suggested that either one of two courses be followed: (a) the foreclosure action should be instituted in the federal court if jurisdiction can be obtained upon the grounds of diversity of citizenship; or (b) if no diversity exists, foreclosure of the copyright mortgage should be accomplished by exercise of the power of sale in the mortgage, and, if the lender is the purchaser at the sale, he should thereafter file a quiet title or declaratory relief action in the appropriate state court in order to obtain judicial sanction for his title. ${ }^{40}$ Even if it is later determined, in a subsequent action, that the judgment rendered by the state court in the earlier quiet title or declaratory relief action was void for lack of jurisdiction, such a determination would not invalidate the sale itself.

${ }^{46}$ I97 F. 2d 767 (9th Cir. 1952).

478 U. S. C. A. 1338 (a) (Supp. 1952).

${ }^{48}$ Security-First National Bank of Los Angeles v. Republic Pictures Corporation, 97 F. Supp. 360 (S. D. Cal. 1951).

${ }^{40}$ If the state courts have exclusive jurisdiction to foreclose a mortgage of copyright, a fortiori they have jurisdiction to entertain a suit to determine title to the copyright. See Luckett v. Delpark, 270 U. S. 496 (1926). 
F. Hypothecation of Less than the Entire Copyright

A comparatively frequent occurrence in transactions involving loans upon the security of literary material arises out of the following circumstances: $A$ writes and becomes the copyright proprietor of a successful novel. $A$ licenses unto $B$ the entire motion picture rights. $B$, while preparing for the production of the motion picture, desires to borrow money to be secured by a mortgage on the motion picture rights to the novel. Can a lien enforceable as against third parties be created by such a mortgage?

Partial assignments or licenses, i.e., transfers of less than the entire copyright, have long been recognized by the courts and other authorities, ${ }^{50}$ notwithstanding the fact that Section 28 of the Copyright Act does not expressly authorize anything less than a transfer of the whole copyright. The doctrine of "indivisibility of copyrights" has fallen into disrepute and in recent years has been limited by the courts to the purely procedural question of whether a transferee of less than all of the rights conferred by copyright is entitled to maintain an infringement action. ${ }^{51}$ Accordingly, it seems clear that there is nothing in the Copyright Act which bars or limits a partial mortgage, i.e., mortgage of less than the entire copyright. ${ }^{52}$

If the lender's rights under his partial mortgage are to be fully protected against the whole world, the mortgage must be an instrument which Section 30 of the Act requires to be recorded. Otherwise recordation of the mortgage will not constitute constructive notice of the mortgage and its lien to subsequent transferees and encumbrancers of the entire copyright or of the same rights; ${ }^{53}$ moreover, with respect

\footnotetext{
${ }^{00}$ See: e.g., Herwig v. United States, 105 F. Supp. 384 (Ct. Cl. I952); Horace G. Ball, The Law of Copyright and Literary Property 534 (1944).

21 The theory that the Copyright Act recognizes only an all embracing indivisible copyright developed in cases in which the courts were confronted with the question of whether a transferee of less than the entire copyright is entitled to maintain an action against infringers. Haunted by the specter of a multiplicity of suits being brought against the infringer, the courts have held that the transferee may not maintain such an action without joining the copyright proprietor. See: e.g., New Fiction Publishing Co. v. Star Co., 220 Fed. 994 (S. D. N. Y. 1915); Goldwyn Pictures Corporation v. Howells Sales Co., 282 Fed. 9 (2d Cir. 1922 ). The concept of the indivisibility of copyright was embodied in a ruling of the Commissioner of Internal Revenue in I. T. 2735, XII-2 CuM. BuLL. I3I (1933), in which the Commissioner ruled that a copyright constituted a single unit of property and that any rights granted thereunder by the author were merely licenses and that amounts paid for the rights granted constituted royalites which were taxable as ordinary income. In recent cases the courts have rejected this view and have held that a grant of one or more of the various rights enumerated in Section I of the Copyright Act constitutes a "sale" of personal property, and, if the other requirements imposed by the Internal Revenue Code are met, the proceeds received by the "seller" will be taxable as long term capital gain, rather than ordinary income. See: e.gi, Herwig v. United States, 105 F. Supp. 384 (Ct. Cl. r952).
}

62 "Nothing in the law of copyrights bars or limits sale of any one of the numerous exclusive rights conferred by the various subdivisions of $\S \mathrm{I}$ [of the Copyright Act]. Congress has not disallowed such sales and nothing in the due enforcement of the Copyright Law suggests their disallowance. Quite the contrary. ... The scheme and details of the copyright legislation manifest a separate treatment of the various exclusive rights conferred by the statute. ... It segregates these rights into separately numbered paragraphs. In each paragraph there is listed, in the alternative, a more detailed subdivision of the various rights. Each of these rights is substantial and exists separately from the others, and has of course been considered a property right." Frankfurter, J., dissenting in Commissioner v. Wodehouse, 337 U. S. $369,420-422$ (1949).

${ }^{33}$ See Horace G. Ball, The Law of Copyright and Literary Property 449-550 (1944). It is generally held that unless required by law the recordation of a document does not operate to give 
to the existence of prior mortgages on the same rights, our lender would not be able to rely on his search of the records of the Copyright Office even though the search disclosed that no prior mortgage on the same rights was of record. The unrecorded mortgage, of which our lender presumably does not have actual notice, being prior in time, probably would prevail. ${ }^{54}$ If the mortgage of less than a whole copyright is subject to the recordation requirements of the Copyright Act, it will be void as against subsequent bona fide transferees for value if not recorded within the statutory period. But if such a mortgage is not subject to Section 30 of the Act, failure to record would not, it would seem, invalidate the mortgage as to subsequent transferees.

There is substantial case authority for the proposition that a license is void as against a subsequent transferee of the copyright or the same rights, for value and without actual notice of the prior license, unless the prior license is recorded in accordance with the recordation provisions of the Copyright Act. At least two cases decided by the Court of Appeals for the Second Circuit so hold. ${ }^{55}$ Although several commentators $^{56}$ on the law of copyright take the position that the Act does not require the recordation of licenses and that, accordingly, recordation will not constitute constructive notice to third parties of the existence of such licenses, the obvious implication of these cases is to the contrary. It would appear, therefore, that the licensee is protected both against prior transferees and subsequent transferees if there is no prior transfer of record in the Copyright Office, and if in addition the licensee records his license within the period allowed by the Copyright Act. And in these respects there would seem to be no reason to treat a partial mortgage differently than a license.

But one of the facts in our hypothetical situation requires special consideration. It will be remembered that $B$, our borrower-mortgagor, is himself a licensee. Does the fact that $B$ is not the "copyright proprietor" change our conclusion as to the validity and recordability of the partial mortgage? Here again the license cases are helpful. The federal courts have long recognized the validity of licenses of rights under a patent executed by individuals who themselves were licensees of the

constructive notice of its contents. E.g.: Rehm v. Reilly, I6x Wash. 418, 297 Pac. 147 (1931); Kendrick v. Colyar, I43 Ala. 597, 42 So. Ixo (1904); Rudolph Wurlitzer Co. v. Cohen, I56 Md. 368, I44 Atl. 64I (I929).

54 See Freeman, The Copyright as Security, I2 J. B. A. Kan. 257, 259 (1942).

¿s Photo Drama Motion Picture Co. v. Social Uplift Film Corp., 220 Fed. 448 (2d Cir. 1915); Brady v. Reliance Motion Picture Corp., 229 Fed. 137 (2d Cir. 19r6); cf. Macloon v. Vitagraph, 30 F. $2 d$ 634 (2d Cir. 1929). The decision of the Second Circuit in Photo Drama Motion Picture Co. v. Social Uplift Film Corp., supra, has been criticized on the ground that the court erroncously considered the instruments of transfer as assignments instead of licenses. Arthur W. WetL, American Coprriour Law 562,563 (I917). However, in its opinion in the same case the District Court (Judge Lcarned Hand) stated: "However, it is really not necessary to consider whether or not this is a license or an assignment, because a license falls before an assignment taken in good faith anyway. It would be absurd to protect a subsequent purchaser against a prior unrecorded assignee and leave him open to prior unrecorded licenses which should defeat him." 213 Fed. 374, 377 (S. D. N. Y. 1914).

${ }^{60}$ arthur W. Weir, american Copyright law 562-564 (rgi7); Horace G. Ball, The Law op Copyright and Literary Property 550 (1944). 
same rights from the patent proprietor. ${ }^{5 \pi}$ The only restriction imposed by the courts is that the agreement between the patentee and the first licensee must expressly permit the further transfer of the rights involved..$^{58}$

In the light of these cases, the lender should make sure that the prior agreement between his mortgagor and the copyright proprietor expressly permits the further transfer of the same rights. If the original license agreement so provides, there would seem to be no reason why the partial mortgage, if properly executed and recorded in accordance with the Copyright Act, would not be valid as against the whole world.

Photo Drama Motion Picture Co. v. Social Uplift Film Corp ${ }^{59}$ is authority for this view. In that case the author of a novel assigned his right to copyright the novel to a publisher. The publisher secured copyright upon the novel and thereafter reassigned all dramatization rights, including motion picture rights, to the author. The author then transferred the motion picture rights to one Totten. Totten did not record his "assignment." Thereafter the author transferred the motion picture rights in the novel to plaintiff, who duly recorded his "assignment." Plaintiff produced and copyrighted a motion picture based on the novel. Subsequently plaintiff filed an action to restrain defendant, Totten's transferee, from producing and selling motion pictures based on the novel. The District Court entered an order granting plaintiff's motion for preliminary injunction. This order was affirmed by the Court of Appeals for the Second Circuit, which held that plaintiff acquired the motion picture rights free and clear of Totten's unrecorded "assignment." Although it is clear that the author was nothing more than a licensee, i.e., a transferee of less than the entire copyright, that fact did not affect the determination that the transfer to Totten was subject to the recordation requirements of the Copyright Act.

\section{G. The Copyright Renewal Problem}

Before bringing our discussion of copyrighted material to a close, a brief reference to the problems presented by the copyright renewal statute is necessary. Section 24 of the Copyright $\mathrm{Act}^{60}$ provides that a copyright shall endure for a period of

${ }_{2}$ Walker on Patents $\$ 388$ (Deller's ed. 1937).

${ }^{68}$ E.g., Karl Kiefer Mach. Co. v. U. S. Bottlers Machinery Co., II4 F. 2 d I69 (7th Cir. I940).

100 Fed. 448 (2d Cir. I914).

${ }_{17}^{17}$ U. S. C. $\$ 24$ (Supp. 1952). This Section provides that: "The copyright secured by this title shall endure for twenty-eight years from the date of first publication, whether the copyrighted work bears the author's true name or is published anonymously or under an assumed name: Provided, That in the case of any posthumous work or of any periodical, cyclopedic, or other composite work upon which the copyright was originally secured by the proprietor thereof, or of any work copyrighted by a corporate body (otherwise than as assignee or licensee of the individual author) or by an employer for whom such work is made for hire, the proprietor of such copyright shall be entitled to a renewal and extension of the copyright in such work for the further term of twenty-eight years when application for such renewal and extension shall have been made to the copyright office and duly registered therein within one year prior to the expiration of the original term of copyright: And provided further, That in the case of any other copyrighted work, including a contribution by an individual author to a periodical or to a cyclopedic or other composite work, the author of such work, if still living, or the widow, widower, or children of the author, if the author be not living, or if such author, widow, widower, or children be not living, then the author's executors, or in the absence of a will, his next of kin shall be entitled to a renewal and extension of the copyright in such work for a further term of 
twenty-eight years from the date of first publication and may be renewed for an additional twenty-eight years by an application filed in the Copyright Office in the twenty-eighth year of the original term by the person entitled to the renewal.

The first point which the lender-should keep in mind is that the people who may obtain the renewal are specifically enumerated in the Act and are more limited in number than those who may take out first rights. With respect to most copyrighted works, only the author, if alive at the time of renewal, is entitled to renew the copyright term, even though he may not be the proprietor of the original copyright. In the case of any "posthumous work" or "other composite work" or of any work "copyrighted by a corporate body (otherwise than as assignee or licensee of the individual author) or by an employer for whom such work is made for hire," the copyright proprietor, who is not the author of the work, is entitled to the renewal. ${ }^{12}$ Thus, to keep his security interest alive during the renewed term, the lender must make sure that his mortgage on the renewal copyright is executed by the person entitled to the renewal. Where the copyright proprietor is not within the class of persons expressly designated by the statute as being entitled to a renewal, the lender may need two mortgages: one mortgage covering the original copyright executed by the copyright proprietor; and a second mortgage hypothecating the renewal copyright executed by the author or other person entitled thereto.

The second point to consider is that the renewal, when secured, is free and clear of any right, interest or license granted under the original copyright. ${ }^{02}$ It is well settled, however, that prior to the renewal period an author may assign his expectancy of the renewal right, but that the effectiveness of the assignment depends upon the survival of the author to the renewal period. ${ }^{63}$ If the author dies prior to the renewal period, i.e., prior to the first day of the twenty-eight year of the original term, the assignment is a nullity. ${ }^{64}$ It would appear, on the authority of the assignment cases, that an author may, prior to the renewal period, also hypothecate his expectancy of the renewal right, and that such hypothecation will become effective if the author is alive on the first day of the twenty-eighth year. Accordingly, in any case in which the copyright proprietor is one of the persons entitled to a renewal, the lender should make certain that his mortgage contains clear and unequivocal language hypothecating the renewal right.

But, the lender should bear in mind that if the author dies prior to the renewal period, the author's right of renewal passes under the statute to his widow, children,

twenty-eight years when application for such renewal and extension shall have been made to the copyright office and duly registered therein within one year prior to the expiration of the original term of copyright: And provided further, That in default of the registration of such application for renewal and extension, the copyright in any work shall determine at the expiration of twenty-eight years from first publication."

${ }^{81}$ See discussion in Shapiro, Bernstein \& Co. v. Bryan, 123 F. 2d 697, 699 (2d Cir. I941).

${ }^{62}$ E.g., Fitch v. Shubert, 20 F. Supp. 314 (S. D. N. Y. 1937); G. Ricordi \& Co. v. Paramount Pictures, 189 F. 2d 469 (2d Cir. I95I).

${ }^{03}$ M. Witmark \& Sons v. Fred Fisher Music Co., r25 F. 2d 949 (2d Cir. I942), affd, 3 I8 U. S. 643 (1943).

os Ibid. 
executor or next of kin. If the author dies prior to the first day of the twenty-eighth year, the prior assignment of his expectancy of renewal does not cut off the rights of renewal extended by the statute to his widow, children, executor or next of kin. ${ }^{65}$ Thus, even if the mortgage expressly covers the author's right of renewal, the death of the author prior to the renewal period will render the mortgage a nullity-as far as the renewal copyright is concerned. To be fully protected against this contingency, the lender would have to obtain a separate mortgage or assignment from the author's potential successor. This presents a considerable problem. It would be most difficult to foretell which persons-widow, children, executor or next of kin-will succeed to the renewal rights upon the death of the author, particularly where the author is a relatively young man and the original copyright term still has many years to run. As a practical matter, the need to obtain a lien on the renewal copyright becomes urgent only if the original copyright has but a short time left to run. Under such circumstances, the lender may find himself faced with the problem of securing mortgages or assignments from a number of persons other than the copyright proprietor. ${ }^{68}$

\section{UNCOPYRIGHTED MATERIAL}

For the purposes of this discussion, the term "uncopyrighted material" refers to any original literary or artistic work which has not been copyrighted under the federal copyright statute, and which has not been dedicated to the public as a result of publication of the work or abandonment of the rights therein. Historically, the phrase "common law copyright" has been used to designate the bundle of rights conferred at common law on the owner of such a work. ${ }^{87}$ Since a common law copyright is lost by publication, the essential common law rights conferred on the owner of an uncopyrighted work are the exclusive right to make first publication of the work and the correlative right to prevent or limit publication. ${ }^{68}$

To begin with, our lender, who desires to make a loan on the security of uncopyrighted material, is faced with the practical problem of making an independent determination as to whether his prospective lien on the work would be subject to any prior transfers or liens. In the case of copyrighted material, the prospective lender may search the records in the copyright office and if he finds no record of a prior transfer or hypothecation he is reasonably assured that his mortgage, if duly recorded in accordance with Section 30 of the Copyright Act, will have priority over the claims of any prior assignee or encumbrancer. ${ }^{69}$ In the case of uncopyrighted matter, no comparable precaution can be taken. A search of the official records of every

\footnotetext{
${ }^{\text {os } I \text { Ibid. }}$

${ }^{\circ 0}$ For a discussion of this problem, see Selwyn \& Co. v. Veiller, 43 F. Supp. 491, 494 (S. D. N. Y. 1942).

${ }^{\circ 7}$ Copyright and Literary Property, I8 C. J. S. 133, I38 ( 1 I et seq.) (1939).

${ }^{\circ}$ Ibid.

${ }^{\circ 0}$ As has already been pointed out, the lender runs the risk that a previously executed mortgage or assignment may be recorded after the lender's mortgage is recorded but within ninety days from the date of its execution, in which event it would prevail over the lender's mortgage. See supra, page 263 .
} 
county or city wherein a prior transaction involving the work might have been consummated obviously would not be feasible. Even if such a comprehensive search could be made, it would be of little value, since it is unlikely that any state requires the recordation of assignments or licenses of uncopyrighted material and it is doubtful if many states require the recordation of instruments creating liens upon such property. In the last analysis, the prospective lender must rely on the good faith of the borrower and on the ingenuity of his counsel in verifying the borrower's representations.

To determine whether a common law copyright may validly be hypothecated, and, if it may, the kind of security device which should be utilized in effecting such hypothecation, lender's counsel must, of course, look to the laws of the governing state jurisdiction. It is not within the scope of this paper to summarize or attempt to summarize the applicable statutory and case law of each of the forty-eight states. At best, the writer can merely point up the kind of problems which lender's counsel can expect to encounter. At the outset, counsel is confronted with the same difficult questions of choice of law, to which reference has already been made in our discussion of copyrighted material. ${ }^{70}$

If the statutes of the governing jurisdiction which regulate the form and recordation of personal property mortgages are broad enough to authorize and regulate the mortgaging of intangibles such as common law copyrights, the problems are greatly simplified. The lender's security interest will be protected against subsequent transferees and creditors by a mortgage prepared, executed, and recorded in accordance with these statutes. ${ }^{\mathbf{7 1}}$ Moreover, compliance with the local statutes will eliminate the risk that at some later date a court may decide that the statutory requirements extend to other forms of security instruments or that a particular security instrument constitued, in effect, an attempted mortgage which was rendered invalid by non-compliance with the mortgage statutes.

The state personal property mortgage statutes may not, however, be applicable to mortgages of intangibles, such as common law copyrights. The New York Lien Law, ${ }^{72}$ for example, provides that every mortgage of "goods and chattels" and certain canal craft shall be absolutely void as against creditors of the mortgagor and subsequent purchasers and mortgagees in good faith and for a fair consideration unless recorded and re-recorded in accordance with the applicable statutory provisions. The New York courts have held that this recording statute does not apply to mortgages on personal property generally, but only to mortgages on personal property which meets the definition of "goods and chattels." T33 Thus, it has been held that an instrument effecting the hypothecation of an intangible such as a claim

${ }^{70}$ See pages $262-263$ supra.

${ }^{71}$ See 1 Leonard Jones, Chatrel Mortgages and Conditional. Sales 379 et seq. (6th ed., Bowers 1933).

\footnotetext{
N. Y. LIEN LAW $\$ 230$ et seq. (1940).

${ }^{73}$ E.g., Niles v. Mathusa, I62 N. Y. 596,57 N. E. 184 (1900).
} 
or demand, ${ }^{74}$ accounts receivable, ${ }^{75}$ a mortgage ${ }^{76}$ or a liquor tax certificate, ${ }^{77}$ is not subject to the recordation requirements of the Lien Law. Moreover, the United States Court of Appeals for the Second Circuit has stated in one case that there is no New York statute regulating the mortgaging of intangibles such as good will and trade-marks. ${ }^{78}$

If there is no local statute regulating the mortgaging of common law copyrights, recourse must be had to the decisional law of the state to determine whether such a mortgage will stand up against creditors of the mortgagor and subsequent transferees. If counsel finds no reliable case authority for the mortgage device, he may find authority in analogous cases for the hypothecation of such property by a security assignment or pledge. In New York, the courts have upheld security assignments of various intangibles. In Harrison $v$. Burlingame, ${ }^{79}$ it was held that the rights acquired by a lender under a security assignment of a mortgage were superior to those of a subsequent bona fide purchaser of the mortgage for value. In Niles $v$. Mathusa, ${ }^{80}$ the New York Court of Appeals held valid, as against the claims of a subsequent judgment creditor, an assignment of a liquor tax certificate given to secure a loan. And the United States Court of Appeals for the Second Circuit, applying New York law, held in Rockmore v. Lehman ${ }^{81}$ that a security assignment of moneys due under a contract was valid as against the trustee in bankruptcy of the assignor. The Illinois courts have upheld, as against the claims of third parties, pledges of such intangibles as a conditional vendor's interest under a conditional sales contract, ${ }^{82}$ a judgment lien, ${ }^{83}$ an interest in a partnership, ${ }^{84}$ moneys due under a lease, ${ }^{85}$ and a seat on a livestock exchange. ${ }^{86}$

Thus, in those jurisdictions in which there is no statutory or case authority for a mortgage of the common law rights in uncopyrighted material, lender's counsel may find case authority for the hypothecation of the property by means of some other security device. In such a jurisdiction, counsel should cast his security instrument in the form approved by the courts in analogous cases.

Since a large number of security transactions of the kind discussed in this paper are consummated in California, it may be profitable to consider some of the problems presented by the unique statutes of that state.

A California statute provides that: ${ }^{87}$

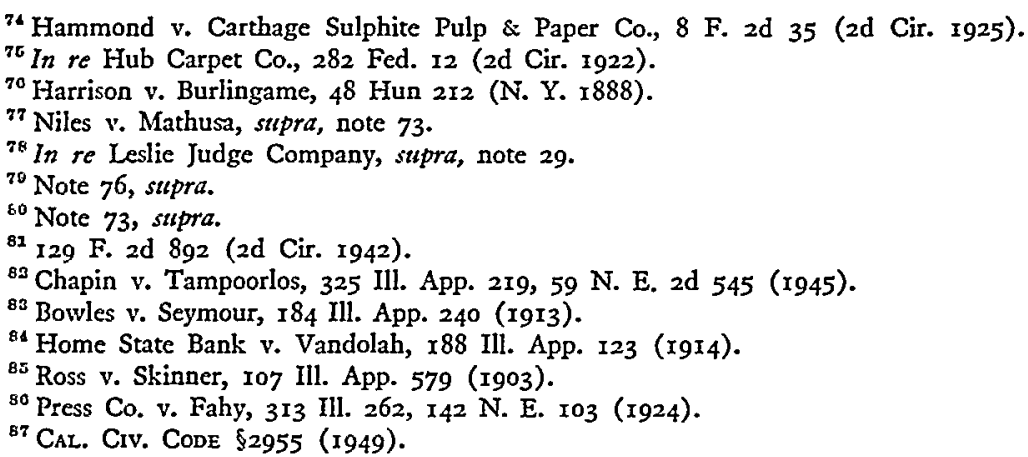


Mortgages may be made upon ... any and all kinds of personal property except ... personal property not capable of manual delivery.

While a mortgage of property "not capable of manual delivery" probably is valid between the parties and persons having actual notice thereof, ${ }^{88}$ such a mortgage would seem to be invalid as against subsequent bona fide transferees for value and attaching creditors of the mortgagor. The recent case of In re Quaker Room ${ }^{80}$ involved an attempt by the owner of a California on-sale liquor license to mortgage it as security for a loan. In a proceeding brought by the trustee in bankruptcy of the "mortgagor" for an order directing the "mortgagee" to turn over the license to the bankrupt estate, the United States District Court for the Southern District of California held that the mortgage may, under California law, be avoided by attaching creditors of the mortgagor, and, therefore, by the trustee in bankruptcy, since a California on-sale liquor license is a species of property "not capable of manual delivery."

A common law copyright obviously falls within the category of "personal property not capable of manual delivery." Thus, under California law, an instrument which on its face clearly and unequivocally purports to mortgage the common law rights in an uncopyrighted work undoubtedly would be invalid as against subsequent bona fide transferees for value and attaching creditors of the putative mortgagor. The statutory prohibition against mortgages of "personal property not capable of manual delivery" does not mean, however, that under California law personal property within this category may not, as against subsequent transferees and creditors, be validly hypothecated by some other security device. In Joint Pole Association $v$. Steele, ${ }^{90}$ the California Supreme Court held that an assignment of money to be paid under a contract, given for security, created a pledge which was good as against an execution creditor of the pledgor, although concededly it did not meet the requirements of the law as to chattel mortgages.

When the result in the Quaker Room case is compared with that in the Joint Pole case, the importance which California law seemingly attaches to the form of the security instrument becomes evident. It is submitted that the attempted hypothecation of the liquor license in the Quaker Room case might well have been upheld had the security document in that case been cast in the form of an agreement of pledge instead of a mortgage. ${ }^{91}$

${ }^{88}$ Id. $\$ 2973$.

${ }^{80} 90$ F. Supp. 758 (S. D. Cal. 1950).

${ }_{00} 2 I_{3}$ Cal. 233,2 P. 2 d 335 (193 I).

${ }^{22}$ Notwithstanding the fact that the security document in the Joint Pole case apparently was in the form of an outright assignment, it would seem advisable, if California law governs the transaction, to draft the security instrument in the form of an express agreement of pledge instead of an assignment. This would eliminate the risk that at some future date a court, subjected to conflicting oral cvidence as to the nature of the transaction, might hold that the assignment constituted an attempted mortgage of "personal property not capable of manual delivery" and therefore is invalid as against a subsequent transferee or creditor. See, e.g., Stewart v. Leasure, 12 Cal. App. 2d 652, 55 P. 2d 917 (1936), in which it was held that a lien on property belonging to a lessee, which was created by a clause in a lease, was subject to a subsequent mortgage on the same property, since the lease was not executed or recorded in accordance with the statutes governing chattel mortgages. 
The use of the pledge device to effect hypothecation of a common law copyright raises a further question. Because of judicial preoccupation with the requirement that possession of the pledged property be delivered to, and retained by, the pledgee, so as to give notice to third parties of the existence of the lien, the early cases seem to have held that only tangible personal property might be made the subject of a pledge. ${ }^{92}$ It can no longer be doubted, however, that many kinds of intangibles may be pledged.93 In the case of a chose in action represented by an "indispensable instrument," such as a bank deposit passbook, stock certificate or life insurance policy, the change of possession requirement is met by manual delivery of the "indispensable instrument" to the pledgee..$^{94}$ However, where the intangible is not represented by an indispensable instrument, only minimal formalities are necessary to constitute delivery of possession. Ordinarily the execution and delivery of an assignment or other writing will constitute all the delivery and change of possession that can be made in the case of such an intangible. ${ }^{95}$ But must additional formalities be complied with to satisfy the possession or notice requirement in the case of a pledge of an uncopyrighted work? To protect his security interest as against subsequent transferees or creditors, should the pledgee-lender require the pledgor to deliver to him the original manuscript or a copy thereof? It can hardly be said that the basic common law rights in the work, i.e., the right of first publication and the right to withhold or limit publication, are "represented" by the manuscript. Accordingly, it would seem that if the governing jurisdiction recognizes a pledge of a common law copyright, the pledge can be effected merely by the execution and delivery of an appropriate agreement or assignment.

The pledgee or mortgagee of a common law copyright, like the mortgagee of a copyrighted unpublished work, is faced with the possibility of an unauthorized publication by the pledgor or mortgagor which might constitute a dedication of the work to the public and thereby render the security valueless. This problem has already been discussed and the discussion need not be repeated here. ${ }^{06}$ Suffice it to say that as a minimum precaution the lender should insist upon the inclusion in the mortgage or pledge agreement of a provision prohibiting or limiting the mortgagor's or pledgor's right to publish the work.

\section{Conclusion}

It is manifest that the problems which confront the lender who undertakes to lend money on the security of literary or artistic property are many and the answers few. The dearth of reported cases on the subject makes counsel's job exceedingly difficult in this field. Perhaps, however, many of the difficulties stem from the abstract character of this kind of property. Justice Holmes once said: ${ }^{97}$

${ }^{\text {9a }}$ Ray A. Brown, A Treatise on the Law of Personal Property 560 et seq. (I936).

${ }^{93} \mathrm{Ibid}$. See, also, cases cited in notes 83 through 86 , supra.

" Note, Security Interests Under Pledge Agreements, 5I YaLE L. J. 43I, 436-437 (r942).

${ }^{05}$ E.g., Joint Pole Association v. Steele, supra, note 90.

${ }^{00}$ Sce supra, pages 255-256.

${ }^{97}$ White-Smith Music Publishing Co. v. Apollo Co., 209 U. S. I, I9 (I908). 
But in copyright property has reached a more abstract expression. The right to exclude is not directed to an object in possession or owned, but is in vacuo, so to speak. It restrains the spontaneity of men where but for it there would be nothing of any kind to hinder their doing as they saw fit. It is a prohibition of conduct remote from the persons or tangibles of the party having the right. It may be infringed a thousand miles from the owner and without his ever becoming aware of the wrong.

It is not surprising that, as collateral, copyright-the right to restrain "the spontaneity of men"-does not fit conventional notions developed in the law of security. 